\title{
A LEGISLAÇÃO INDÍGENA: ambigüidades na formação do Estado-Nação no Brasil
}

\author{
Carlos Henrique Gileno*
}

\section{HISTÓRIA SUCINTA DE UMA QUESTÃO ABRASADORA}

Decerto a escravatura nas Américas não se restringiu ao tráfico de escravos africanos, tampouco as relações raciais estiveram limitadas aos contatos socioeconômicos e culturais estabelecidos entre brancos e negros (Skidmore, 1973, p. 76). Exemplo desse fato podemos encontrar no caráter ambíguo da legislação indigenista efetivada desde meados do século XVI até a segunda metade do século XIX, no Brasil.

Esse caráter ambíguo da legislação referente aos índios foi analisado pelo jurista campineiro Rodrigo Octavio de Langgaard Meneses (1866-1944) durante um curso ministrado na Academia de Direito Internacional de Haia, em julho de 1930, intitulado Les Sauvages Américains devant le Droit, onde o autor abordou a questão da legitimidade ou ilegitimidade da escravidão indígena perante o direito internacional. Nesse curso, Rodrigo Octavio

* Professor-Doutor. Instituto Matonense Municipal de Ensino Superior (IMMES). Avenida Tiradentes, 629, Centro. Cep: 15990-185, Matão - São Paulo - Brasil. Fone: (16) 3384-1851. cgileno@uol.com.br apontava que a condução da atividade colonizadora dos países da península ibérica no continente americano era motivada por um sentimento de dominação. Para ilustrar tal sentimento, Rodrigo Octavio citou o professor e diplomata argentino, Enrique Ruiz Guinazú. A conquista, a nosso ver, era uma guerra: a ab-
sorção do fraco pelo forte; o triunfo de uma raça
superior, bela, inteligente, progressista, sobre o
indígena sem virtude, infestado de vícios, cheio
de ignorância e vivendo na incultura. Suplantar
essa raça era, em tal caso, obedecer a uma lei
natural, inevitável e permanente. Por essa ra-
zão, a generalidade das declaraçóes reais foi
tida como lamentável. Era preciso aplaudi-las.
Mas a crítica histórica as reduziu a nada
(Guinazú apud Octavio, 1946).

De fato, a ambigüidade da legislação indígena provinha dos conflitos estabelecidos entre índios, colonos, jesuítas e o governo metropolitano. Na Segunda Parte do ensaio A Escravidão no Brasil (1864-1867), o jurista mineiro Agostinho Marques Perdigão Malheiro (1824-1881) narrou igualmente as violações dos colonos das leis expedidas pela coroa portuguesa e que estabeleciam a liberdade dos índios. 
Esses “abusos" estavam permeados pela ausência de unidade e centralização do governo metropolitano na colônia durante o início do século XVI, uma vez que os donatários possuíam liberdade de couto e homizio nas capitanias, ou seja, as leis provenientes da coroa portuguesa não eram consideradas em seus respectivos territórios. Énesse contexto que o primeiro Governador Geral, Tomé de Souza, procurou estabelecer o princípio da unidade e centralização de um governo na colônia.

Contudo, tanto a incipiente busca da unidade territorial quanto a tentativa de centralização administrativa colonial não extinguiram a guerra movida aos índios. Por exemplo, o Regimento de 17 de dezembro de 1548 propugnava a conversão dos índios à fé católica - proibindo a guerra contra os indígenas amigos. Porém o citado Regimento desnudava, mais uma vez, a ambigüidade da legislação, pois ordenava "a guerra aos que se mostrassem inimigos... destruindo-lhes as aldeias e povoações, matando e cativando... e fazendo executar nas próprias aldeias alguns chefes que pudesse aprisionar enquanto negociasse as pazes (!)" (Malheiro, 1976, v. 2, p. 165).

Em contrapartida, a guerra movida contra os índios inimigos incitaria sua reação guerreira, reação que permitiu aos indígenas obterem vitórias militares ao sul da colônia lusitana - motivando a resolução da Carta Régia de 1557, a qual legalizava o cativeiro dos Caetés. ${ }^{1}$ Essa Carta Régia fez emergir a implantação de um sistema de terror contra os índios inimigos, assinalando-se a guerra aberta contra eles.

Os selvagens persistiam por sua parte em infestar a terra com suas assaltadas; formando mesmo alianças entre si contra os Portugueses, como foi a celebrada Confederação dos Tamoios, conjurada pelos esforços dos Jesuítas e sobretudo do Padre José de Anchieta; e auxiliando os estrangeiros, quais os Franceses, contra os colonos. - Acaso eram eles instigados pelo espírito do mal? Ou tal estado de coisas teve sua causa originária no fato não interrompido das vexações exercidas pelos colonos contra os pobres índios, fossem amigos e pior se inimigos? Sofrendo agora os atuais colonos as conseqüências das culpas dos antecessores, e quiçá da sua própria? (Malheiro, 1976, v. 2, p. 169, grifos meus).

${ }^{1}$ Cf. Malheiro, 1976, v. 2, p. 169; Octavio, 1946, p. 84.
A ambigüidade da legislação colonial estava presente no fato de que a metrópole recomendava que se mantivesse a liberdade dos indígenas. A coroa portuguesa reconheceu que os colonos mantinham os índios aprisionados "por modos ilícitos", já que o cativeiro só seria legítimo nos casos em que os índios fossem subjugados por intermédio de uma guerra justa, a qual teria de ser aprovada por uma Licença Régia ou pelo Governador.

No primeiro decênio do século XVII, a Lei de 30 de julho de 1609 confirmava a disposição da metrópole em atenuar a servidão nativa (Malheiro, 1976, v. 2, p. 177). Devemos lembrar que essa disposição metropolitana estava inserida num contexto de decadência do objetivo inicial jesuítico de consolidação da civilização e do cristianismo ocidentais entre os indígenas. No alvorecer dos setecentos, os padres da Companhia de Jesus "executavam” a escravidão indígena em seus domínios posto que as leis referentes aos índios estariam quase exclusivamente submetidas à "tutela" dos jesuítas-, utilizando a mão-de-obra compulsória indígena nas suas empresas agrícolas e comerciais, não consentindo que os colonos cativassem os indígenas localizados nos sertões ou retirassem os "índios domesticados" das aldeias ou povoações.

Foi nesse cenário que as bandeiras, sobretudo em São Paulo, realizaram o apresamento dos "índios bravos fora da jurisdição dos padres", surgindo ainda diversas representações - principalmente da Câmara da Paraíba - dirigidas à metrópole, alertando-lhe, nas representações de 19 de abril e 8 de maio de 1610, que as violências recíprocas praticadas entre colonos e nativos estavam exacerbadas, receando-se o degolamento mútuo.

Assim, surgiu a reivindicação dos colonos de se retirar o poder temporal dos jesuítas, aventando-se mesmo a hipótese defendida pelo então governador-geral D. Diogo de Menezes de se extinguir o sistema de Aldeias (p. 180). A Lei de 10 de setembro de 1611 confirmava o retorno da escravidão indígena sob a chancela da coroa portuguesa, a qual ainda reconhecia "em tese" a liberdade dos índios, prevendo-se punições aos infratores.

Em verdade, o sistema de administração dos 
índios, no estado doMaranhãoe Grão-Pará seiscentista, estava sob o poder dos colonos. Por intermédio de uma sublevação, os colonos conseguiram anular a determinação da Câmara expressa no Alvará de 8 de junho de 1625, que proibia o governo de colonos nas aldeias (Cf. Alencastro, 2000).

Nesse período, o referido sistema de resgates prevaleceu e, no sul da colônia, vigorou também a caça aos índios, inclusive no interior das reduções jesuíticas. Por outro lado, a bula do Papa Urbano VIII - que determinava a excomunhão dos colonos que cativassem e comercializassem índios - fez com que novamente o "povo" se insurgisse na colônia. O então Governador Salvador Corrêa de Sá e Benavides - apesar da sua proteção às pretensões de domínio temporal jesuítico sobre os indígenas ao longo do território colonial português na América - restringiu o poder dos jesuítas sobre a administração dos índios apenas às suas aldeias, proibindo-lhes ainda - por intermédio do Acordo de 22 de junho de 1640 - de admitirem escravos particulares em seus territórios.

A perda paulatina do poder temporal jesuítico sobre os indígenas foi o principal motivo da viagem do Padre Antônio Vieira à corte portuguesa, retornando com a possibilidade de se implantar a Junta das Missões, que permitia aos Padres da Companhia de Jesus o direito de realizar as entradas nos sertões (Cf. Malheiro, 1976, v.2, p. 188).

Igualmente, durante os seiscentos, os jesuítas realizaram os descimentos - uma das formas legais de apropriação da mão-de-obra indígena ao lado do cativeiro e do resgate. Enquanto o cativeiro era legítimo, se motivado por uma guerra justa, reconhecida pela autoridade régia, os descimentos visavam a forçar a retirada das etnias indígenas dos seus territórios, transplantando-as para os territórios europeus fixados em solo americano (Alencastro, 2000, p. 119-120).

Com efeito, a partir de meados dos seiscentos, os Padres da Companhia Jesus iriam se utilizar dos seus poderes temporais para seguir as mesmas estratégias de domínio sobre os indígenas de que se valiam os colonos. A elevada tensão entre os referidos padres e colonos formou um partido de oposição aos jesuítas na colônia luso-americana, ocorrendo uma sublevação dos colonos em 1661, em que vários padres da companhia - inclusive Antônio Vieira - foram presos e conduzidos até Lisboa. Esse fato motivou a efetivação da Lei de 12 de setembro de 1663, a qual obstava o exercício da jurisdição temporal jesuítica sobre os índios. Em verdade, esse confronto entre índios, jesuítas, colonos e governo metropolitano traduzia a relativa ineficácia da aplicação das leis coloniais provenientes da metrópole.

A violação das determinações régias era reconhecida pela metrópole lusitana no Alvará de 1691, o qual regulava as multas que deveriam ser aplicadas aos colonos que escravizassem índios sem a chancela régia. O protesto dos colonos contra esse alvará vinha embasado na constatação de que a escravização indígena era necessária como fornecedora de braços para o trabalho. Todavia podemos dizer que as principais causas que fomentaram a escassez de mão-de-obra eram a peste, os excessivos tributos que obstaculizavam o desenvolvimento da indústria e da lavoura, as perseguições da Santa Inquisição e a gestão tíbia tanto da administração colonial quanto metropolitana sobre a organização política da colônia.

Quando se referiu à peste como um entrave à utilização da mão-de-obra indígena, Perdigão Malheiro destacou um dos elementos fundamentais que reduziram a possibilidade de um emprego amplo da mão-de-obra indígena, seja escravizada ou livre. Esse assunto é retomado pelo historiador Luiz Felipe de Alencastro no seu excelente estudo sobre a formação do Brasil no atlântico sul nos séculos XVI e XVII. É interessante notar os dados epidemiológicos, referentes aos índios, arrolados pelo autor, uma vez que demonstram os diversos fatores da dispersão de moléstias entre os indígenas, motivadas, sobretudo, pelo contato com outras etnias.

Os aldeamentos transferem comunidades isoladas, reagrupando-as na proximidade dos portos e do novo campo patogênico formado por europeus e africanos. Nos primeiros meses, antes do preparo dos roçados e das primeiras colheitas do milho e da mandioca, a má alimentação acentuava a morbidade e a mortalidade dos índios 
aldeados. Nos enclaves coloniais, a derrubada do mato e o avanço dos canaviais facilitaram a proliferação dos mosquitos e das febres. Tais circunstâncias levaram os nativos do litoral atlântico da América do Sul a sofrer em cheio o impacto da unificação microbiana do mundo. De conseqüências decisivas no mercado de trabalho e na sociedade colonial, a brasilianização das doenças européias e africanas mereceria ser investigada de maneira transdisciplinar, a exemplo dos estudos efetuados sobre a Peste Negra no Ocidente trecentista (Alencastro, 2000, p. 128).

Podemos dizer que a questão da proliferação da peste, como um empecilho à aquisição de mão-de-obra indígena, foi um dos espectros constantes no mundo escravocrata luso-americano. Ao lado da guerra justa, dos resgates e dos descimentos, a peste se constituiu num elemento que impulsionava diversas estratégias de defesa indígena perante a dominação européia (Monteiro, 1992, p. 107).

Cabe ressaltar que o tema deste artigo está centrado, fundamentalmente, nas características resultantes da ambigüidade da legislação indigenista. No primeiro quartel dos setecentos, a Provisão de 5 de julho de 1715 puniu o capitãomor José da Cunha França d’Eça por “prender o procurador dos índios, contra os seus privilégios, pelo fato de estar ele requerendo a bem dos mesmos e contra as violações das leis" (Malheiro, 1976, v. 2, p. 202), evidenciando a perplexidade, a luta e a contradição presentes nas relações estabelecidas entre o governo metropolitano e os colonos, nas questões referentes à escravidão dos índios. Perplexidade, luta e contradição que originaram a pressão dos colonos para a aquisição de mão-de-obra indígena, motivando a expedição da Provisão de 9 de março de 1718, restabelecendo a legitimidade da escravidão nativa (p. 202-203).

As tensões que permeavam as relações entre jesuítas, colonos e governo metropolitano se agravaram a partir da segunda metade dos setecentos. Recomendando a reforma da Companhia de Jesus em Portugal e em todos os seus domínios de além-mar, a bula de $1^{\circ}$ de abril de 1758 do papa Benedito XIV retirou dos jesuítas as suas forças vitais, que se mantinham sobre os direitos de comerciar, confessar e pregar.

Obstada desses direitos, a Companhia de
Jesus seria ainda acusada pela frustrada tentativa de assassinato, em 3 de setembro de 1758, do então monarca lusitano D. José I. Essa acusação, acompanhada da sublevação dos jesuítas na colônia contra a metrópole, provocou a expedição das Cartas Régias de 19 de janeiro e 28 de junho de 1759, as quais, respectivamente, ordenavam a reclusão dos jesuítas, o seqüestro de seus bens e a anulação do direito de ensinar.

Essas medidas do governo metropolitano em relação à Companhia de Jesus marcavam o arrefecimento da preponderância político-econômica conquistada pela coroa lusitana no cenário quinhentista da Europa ocidental. Ao analisar as leis referentes aos índios, expedidas pela metrópole portuguesa em meados do setecentos, Perdigão Malheiro ressaltou a importância da administração pombalina para a consolidação do poder político metropolitano sobre os poderes locais personificados tanto nos colonos quanto nos jesuítas.

Aquele grande estadista, no intuito de maior desenvolvimento da riqueza, poder, e influência do Reino, ao mesmo tempo que se ocupava seriamente de excitar as forças da Nação, dirigia as suas vistas de águia para as colônias, merecendoIhe especialíssima atenção o Brasil pelos recursos que dele tirava a Metrópole, pela sua extensão, grandeza e riquezas naturais, e pelo seu progresso material e intelectual não obstante as peias que o regime colonial sempre opusera (Malheiro, 1976, v. 2, p. 209, grifos meus).

De acordo com o jurista mineiro, a administração pombalina procurou superar o atraso material e intelectual que os poderes locais de colonos e jesuítas perpetuavam tanto na metrópole quanto na colônia. Efetivamente, o tema do atraso no Portugal do século XVIII anunciou tanto a crise do antigo sistema colonial como a difusão das idéias ilustradas que emergiram da nova fase de acumulação capitalista apoiada no industrialismo.

As teorias do iluminismo tomaram um impulso notável nos países onde o desenvolvimento econômico se tornara mais intenso, e Portugal vivenciando ainda as influências inquisitoriais encontrava-se em descompasso em relação ao movimento ilustrado europeu. A administração pombalina conduziu as reformas concernentes à modernização portuguesa por intermédio de um 
conjunto de reformas institucionais que se realizaram mediante o fortalecimento do poder do Estado, atenuando abruptamente as influências de colonos e jesuítas na esfera política.

Ao lado das reformas institucionais que objetivavam o fortalecimento do Estado, as reformas econômicas - traduzidas tanto na recuperação dos mercados ultramarinos como no impulso do setor manufatureiro patrocinado pela intervenção estatal - foram impostas de "cima para baixo", com o Estado assumindo uma postura autoritária. A reflexão sobre o atraso português ofereceu feições próprias às ideologias liberais, pois, se essas ideologias preconizavam a redução do intervencionismo estatal, aquela limitação era impraticável nos países onde o desenvolvimento econômico propiciado pelo industrialismo se realizara tardiamente. Portanto, a ideologia da política reformista lusitana selecionaria do pensamento ilustrado europeu as idéias que melhor se adaptariam às reformas portuguesas. (Novais, 1995).

Nessa adaptação, a ideologia norteadora das reformas pombalinas preconizava o desenvolvimento conjunto da metrópole e da colônia, mas sem a remoção do pacto colonial. A continuidade do pacto, defendida pelos ilustrados portugueses, demonstrava a crença de que Portugal poderia entrar no ritmo da história ocidental conciliando os interesses da metrópole e da colônia. É importante lembrar que, durante esse período, as idéias ilustradas assumiram um caráter revolucionário no Brasil: se, na metrópole, a ilustração adquiriu um aspecto reformista, na colônia, tanto a Inconfidência Mineira (1789) quanto a Conjuração Baiana (1798) denotavam a crítica veemente que as idéias emancipacionistas dirigiam ao funcionamento do antigo sistema colonial mercantilista. No período pombalino - apesar de ainda se estender “a perpétua questão de Índios" - estava em marcha o desenvolvimento intelectual e material tanto na metrópole quanto na colônia (Cf. Malheiro, 1976, v.2, p. 203).

\section{A INTEGRAÇÃO DOS ÍNDIOS NA INVENÇÃO DANAÇÃO}

Perdigão Malheiro - ao se referir ao progresso material e intelectual da colônia, proporcionado pela administração pombalina - era partidário da concepção de que o processo de transição, consubstanciado na reorganização do Estado, deveria ser realizado por uma elite portadora de liderança material e intelectual. E essa dupla liderança foi exercida por Pombal num cenário em que a inversão do pacto se destacou como um dos fenômenos característicos da derradeira etapa do sistema colonial.

Se a inversão do pacto britânico permitiu aos ingleses controlarem politicamente as mudanças ocorridas nas suas colônias, a peculiaridade da inversão do pacto colonial lusitano patenteou a enorme importância da colônia, sobretudo após a perda da soberania portuguesa, advinda da invasão francesa. Nesses termos, a corte lusitana não hesitou em perder temporariamente a metrópole, transferindo-se para o Brasil, numa última tentativa de impedir a independência brasileira e proteger os seus extensos domínios ultramarinos. A crise do antigo sistema colonial mercantilista evidenciou as tensões que caracterizavam tanto as reformas quanto as revoluções condutoras do processo de transição de "uma economia colonial para uma economia mercantil-escravista nacional” (Mello, 1988, p. 53).

Reforma e revolução aparecem, assim, como vertentes do mesmo processo de reajustamento e ruptura na passagem para o capitalismo moderno, na segunda metade de Setecentos e primeira de Oitocentos. E, com efeito, o "despotismo esclarecido" esforçava-se em promover, ao mesmo tempo, a modernização do absolutismo metropolitano a aberturas no sistema colonial. Portugal enveredou muito cedo por esse caminho, a partir do "consulado" pombalino (1750), mas é, sobretudo a partir de 1777 (queda do marquês de Pombal, após a morte de D. José), que se estimula mais claramente a nova política colonial do reformismo ilustrado. Tal reformismo, entretanto, não logra abrandar, antes acentua as tensões, e as "inconfidências" marcam o contraponto revolucionário do processo. Essas as linhas de força que se desenlaçam com a vinda da Corte para o Brasil, em 1807 (Mota; Novais, 1996, p. 25-27). 
A exacerbação dessas tensões também estava expressa nas reformas que fomentaram, no início dos oitocentos, a instauração de uma política de guerra aberta contra os denominados índios bravos. A política de aplicação da violência direta de D. João VI contra essas populações indígenas interrompeu brevemente a retórica secular de que as guerras contra os índios deveriam possuir caráter apenas defensivo, com a sua civilização e cristianização sendo entendidas como elementos que os fariam participar da sociedade civil. Se, em 1806, os índios da Bahia são atacados pelas forças militares do Império luso-americano, as disposições das Cartas Régias de 13 de maio e 5 de novembro de 1808 recomendavam, respectivamente, tanto a guerra contra os índios Botocudos, em Minas Gerais, quanto contra os Bugres em São Paulo, desnudando uma legislação que propugnava a guerra aberta contra os índios bravos, como seria o conteúdo da Carta Régia de $1^{\circ} \mathrm{de}$ abril de 1809.

Aqui [na Carta Régia de $1^{\circ}$ de abril de 1809] manda-se fazer guerra ofensiva para aterrar e subjugar os índios, quer pela tropa, quer por bandeiras; e, ao mesmo tempo que se recomenda a intervenção de religiosos que catequizem, batizem, e instruam os índios, se ordena que a tropa seja ajudada até de artilharia! e mais ainda, se restabelece a escravidão (embora temporária) dos prisioneiros, por 15 anos a contar do dia em que fossem batizados! sem excetuar os velhos, mulheres, e crianças! não se devendo para os impúberes contar esses 15 anos senão desde que tivessem chegado à puberdade! (Malheiro, 1976 v.2, p. 228).

As estratégias de defesa dos índios perante essa legislação eram os ataques constantes aos moradores, bem como as fugas para os sertões situados além dos enclaves europeus. Embora, diante desses acometimentos, as elites políticas reconhecessem que a ferocidade indígena fora incitada pela legislação expedida pela coroa portuguesa no início dos oitocentos, admitiam que essa ferocidade teria de ser freada pela destruição sumária das etnias sublevadas.

[Para impedir] que a nação Canajá continue nas suas correrias, será necessário usar contra ela da força armada; sendo este também o meio de que se deve lançar mão para conter e repelir as nações Apinagé, Xavante, Xerente, e Canoeiro; porquanto, suposto que os insultos que elas praticam tenham origem no rancor que conservam pelos maus tratamentos que experimentaram de alguns Comandantes das aldeias, não resta presentemente outro partido a seguir senão intimidálos, e até destruí-los, se necessário for, para evitar o dano que causam (Trecho da Carta Régia de 1811 apud Malheiro, 1976, v. 2, p. 230-231).

A violência direta contra os índios bravos utilizada por D. João VI cedeu espaço - após a Independência de 1822 - novamente aos argumentos da brandura e conciliação como elementos que poderiam integrar os referidos índios à nação. Entretanto, os argumentos da brandura e conciliação eram parte de um sistema misto, suposto harmonizador do sistema de força e terror contra os índios bravos com o sistema brando e conciliatório. A brandura e a conciliação prevaleceram nas relações com as etnias que se "sujeitassem por bem”, enquanto o terror e a força predominaram contra os índios inimigos.

Os discursos acerca da conciliação branda e da violência direta se interpenetravam. Segundo Perdigão Malheiro, o referido sistema misto apenas animava contra-sensos, uma vez que "a triste realidade foi recrudescer o ódio [dos índios] contra os cidadãos, e a destruição dos índios, ou sua dispersão fugindo assim à civilização, a que, aliás, eram convidados com pólvora e bala, e com o cativeiro ou servidão” (p. 231). Podemos observar que Perdigão Malheiro rejeitou a submissão dos índios à civilização européia ocidental por intermédio da força, da guerra e da escravidão. Com efeito, a integração dos índios a uma nação que ainda estava para ser constituída fez parte de um contexto histórico em que o tema da questão nacional foi fundamental para se formularem projetos políticos que viabilizassem a construção do Estado-nação.

Durante o século XIX, enquanto a sociedade estava apoiada no regime de trabalho escravo, o debate nacional polarizou-se em termos de indianismo, inicialmente, e europeísmo, depois. Logo após a Independência houve um surto indianista. A mesma literatura que trabalhava o mito da raiz indígena da sociedade brasileira, trabalhava também uma imagem mais abrangente da sociedade brasileira como um todo. Ao privilegiar o índio, mesmo não lidando, 
maiormente com os outros, a poesia de Gonçalves Dias e o romance de José de Alencar situavam e articulavam escravos e livres, índios, negros e brancos, portugueses e brasileiros, ou raça, população e povo. Da mesma maneira, o indigenismo inicial de José Bonifácio e Varnhagen também entrava na elaboração da fisionomia da população brasileira. Todos estavam inventando a nação (Ianni, 1987, p. 345).

José Bonifácio de Andrada e Silva (17631838) pensava a questão indígena dentro de um projeto político que procurava acelerar o processo de miscigenação das diversas etnias existentes no território brasileiro, processo esse considerado fundamental para a consolidação da sociedade civil. Ao mesmo tempo em que defendia tanto a abolição gradual da escravatura como a extinção do tráfico negreiro, José Bonifácio afirmava que a miscigenação era um elemento decisivo para a constituição de uma nação homogênea, onde a heterogeneidade física e civil deveria ser debelada pela ligação de "tantos elementos discordes e contrários, e em amalgamar tantos metais diversos, para que saia um todo homogêneo e compacto, que não esfarele ao pequeno toque de qualquer convulsão política" (Andrada e Silva, 1998, p. 48-49).

Na idéia de nação homogênea bonifaciana, a formação tanto do povo quanto da identidade nacional teria de se fundar no desenvolvimento de uma determinada homogeneidade étnica e cultural. A busca dessa homogeneidade estava sendo dificultada pelas tensões estabelecidas entre os índios bravos e os proprietários territoriais. Ao tratar sobre esse assunto no projeto entregue à apreciação da Assembléia Geral Constituinte e Legislativa de 1823, José Bonifácio começava os seus Apontamentos para a Civilização dos Índios Bravos do Brasil formulando uma imagem sobre os habitantes autóctones da América que perpassou a imaginação européia durante séculos.

Se Michel de Montaigne (1533-1592) considerou as qualidades dos indígenas "vivas, vigorosas, autênticas, úteis e naturais" - com a civilização ocidental procurando adaptar a cultura indígena ao seu "gosto corrompido" (Montaigne, 1991, p. 98-104) - José Bonifácio descreveu as características sociais e psicológicas dos indígenas de for- ma menos lisonjeira que a levada a cabo pelo citado filósofo quinhentista.

Povos vagabundos, fomentadores de guerras ininterruptas entre as tribos, portadores de paixões desenfreadas por não possuírem nenhuma peia civil ou religiosa - daí a impossibilidade de se sujeitarem a "leis ou costumes regulares" -, os indígenas bonifacianos ainda estavam entregues a uma preguiça natural. Por fim, os índios se recusavam a aceitar a fé católica para não abandonarem tanto as suas bebedeiras constantes como o seu modo de vida poligâmico que inspirava o divórcio voluntário (Andrada e Silva, 1998, p. 89-90). José Bonifácio também reconhecia que a ferocidade nativa fora incitada tanto pela legislação metropolitana quanto pela desapropriação das terras indígenas.

O desprezo, com que geralmente os tratamos, o roubo contínuo de suas melhores terras, os serviços a que os sujeitamos, pagando-lhes pequenos ou nenhum jornais, alimentando-os mal, enganando-os nos contratos de compra, e venda, que com eles fazemos, e tirando-os anos e anos de suas famílias, e roças para os serviços do Estado, e dos particulares; e por fim enxertando-lhes os nossos vícios, e moléstias, sem lhes comunicarmos nossas virtudes, e talentos (p. 91).

José Bonifácio reprovava a guerra aberta contra os índios bravos como a única alternativa de sujeição dos mesmos à civilização ocidental e ao cristianismo, e os meios brandos e conciliatórios deveriam fazer parte da estratégia de conversão e civilização. Por conseguinte, o autor defendeu os métodos brandos e conciliatórios utilizados pelos jesuítas na conversão dos gentios, porém, cautelosamente, sugeria presídios com algum destacamento militar nas aldeias para proteger os missionários dos "tumultos" e "desordens" que porventura viessem a praticar os índios aldeados (p. 105).

O que acaba vigorando na prática é um compromisso: nas rotas ou regiões que se quer desinfestar de índios - por exemplo, no Rio Doce no início do século e na rota do Tocantins e Araguaia a partir da metade do século - estabelecem-se presídios, como eram então chamados, ou seja, praças-fortes com destacamentos militares. Estes presídios, que pretendem se tornar núcleos de futuras povoações,combatem os índios que resistem e instalam os índios que logram atrair em aldeamentos, como reserva de remeiros, de agri- 
cultores e, mais tarde, de fornecedores de lenha para a lavoura (Cunha, 1992, p. 137).

O discurso acerca da brandura e conciliaÇão de José Bonifácio não o fez descuidar das relações tensas que se firmaram entre as populações nativas e os proprietários territoriais. A idéia bonifaciana de que a religião cristã e a cultura do ocidente europeu industrializado poderiam ser impostas aos hábitos e costumes indígenas - pois "Newton se nascera entre os Guarani seria mais um bípede, que pisara sobre a superfície da terra. Mas um Guarani criado por Newton talvez que ocupasse o seu lugar" -, foi um dos elementos fundamentais na elaboração da fisionomia de uma nação a ser inventada, uma vez que os nativos eram paulatinamente introduzidos ao trabalho regular e disciplinado, exigido pela acumulação de capital apoiada no industrialismo nascente.

As 44 propostas expressas por José Bonifácio nos Apontamentos para a Civilização dos Índios Bravos do Brasil visavam à integração dos índios a uma nação que deveria extinguir gradualmente a escravidão e, concomitantemente, criar hábitos regulares de trabalho entre os indígenas, uma vez que "nas atuais circunstâncias do Brasil e da política européia, a civilização dos índios bravos é objeto de sumo interesse e importância para nós” (Andrada e Silva, 1998, p. 102).

Essas circunstâncias, durante o primeiro quartel do oitocentos, eram criadas tanto pela crescente supremacia do capital industrial sobre o capital mercantil quanto pelo citado declínio do sistema colonial luso-americano instaurado no século XVI. As reformas concernentes à questão indígena eram equacionadas a partir das ambigüidades presentes na constituição do Estado nacional, ambigüidades essas que se expressavam na convivência entre liberalismo e escravidão.

Essa convivência ambígua fomentou o discurso que mesclava os meios brandos e conciliatórios e a aplicação da violência direta contra os índios bravos. A questão da violência contida nas relações entre senhores e escravos - índios ou negros - foi fundamental para que os proprietários territoriais mantivessem o controle da instituição

escravocrata sobre um terreno onde as sublevações e revoltas constantes poderiam produzir o desmoronamento do Estado imperial (Cardoso, 1962, p. 271).

A partir da descrição da Lei de 27 de outubro de 1831 - que estabelecia a abolição formal do cativeiro indígena -, Perdigão Malheiro reafirmou a tendência do Estado imperial em promulgar leis que viessem a abrandar as relações com os indígenas, porém surgiria a recorrente ambigüidade herdada da legislação colonial: uma legislação caracterizada pela ausência de respaldo político para a sua aplicação efetiva entre os poderes locais. A citada lei suspendia a aludida guerra aos índios Botocudos e Bugres, bem como declarava livres todos os índios que permaneciam em estado servil, porque na condição de órfãos a serem tutelados pelo Estado .

\begin{abstract}
Foi, portanto, reprovado formalmente pelo legislador o sistema de terror e da perseguição; foi abolido de uma vez para sempre o cativeiro ou servidão mesmo temporária dos índios, ainda quanto a pretérito; foram eles equiparados aos órfãos e postos debaixo da proteção dos respectivos Juizes; socorridos pelo Tesouro Público enquanto necessitassem; e finalmente incumbida aos Juizes de Paz nos seus respectivos distritos a defesa e guarda da liberdade dos mesmos índios (Malheiro, 1976, v. 2, p. 237).
\end{abstract}

Se o Aviso de 31 de julho de 1834 dispunha que as Câmaras Municipais deveriam garantir a intervenção dos Juizes de Órfãos na defesa legal dos direitos indígenas, a Lei de 12 de agosto de 1834 declarava que as recém-criadas Assembléias Legislativas Provinciais deveriam conduzir, juntamente com a Assembléia Geral e o Governo, o processo de catequese e civilização dos índios. Civilização e catequese que motivaria a Lei n. 285 de 21 de junho de 1843, a qual regulava a vinda dos missionários capuchinhos, e a conseqüente aprovação do Plano das Missões elaborado por esses missionários pelo Governo imperial.

Esse plano compôs o Regimento das Missões de 1845, prevendo que tanto a conversão ao cristianismo quanto a educação religiosa e a instrução primária dos índios ficariam a cargo dos mencionados missionários. Por conseguinte, o ci- 
tado Regimento proibia a aplicação da violência direta contra os aldeamentos de índios, bem como incentivava a miscigenação dos índios entre si e com outras raças. Por outro lado, os índios seriam obrigados tanto a prestar serviço público quanto o serviço na aldeia - ambos mediante salário -, sendo o alistamento militar também obrigatório.

Apesar dessas disposições contidas no Regimento das Missões, a escravização dos indígenas continuava a ocorrer nas províncias. O Aviso de 15 de junho de 1850 censurava as hostilidades promovidas pelo Presidente do Mato Grosso aos índios bravos. Não obstante, os ataques constantes dos índios bravos aos povoados, fazendas e quilombos se fariam presentes no último quartel dos oitocentos.

A guerra particular-que não possuía a chancela régia - movida pelos proprietários territoriais aos índios da Bahia em 1864 e a invasão das aldeias dos Xavantes em 1865, bem como as tropas enviadas pelo Governo imperial ao Paraná e Mato Grosso para repreender as arremetidas dos índios, demonstravam a ineficácia da execução dos regulamentos que compunham o Regimento das Missões.

Os abusos contra os desgraçados índios praticavam-se quase como em todos os tempos anteriores, partindo mesmo dos Diretores, que, em vez de protetores, se têm quase no geral mostrado ou indiferentes, ou perseguidores. E até, por falta de pessoal habilitado, as aldeias não têm sido regidas convenientemente, nem têm sido possível, desenvolver os sistema de tais colônias e do citado regimento (Malheiro, 1976, v. 2, p. 243-244).

Devemos notar que Perdigão Malheiro era partidário da referida idéia bonifaciana de que tanto a religião cristã quanto o padrão civilizatório da Europa ocidental poderiam ser incorporados aos indígenas sem que fosse levada a cabo a violência direta contra essas etnias como o único meio de trazê-las à civilização. Nesses termos, o jurista mineiro refutou uma "outra opinião extrema, sustentada ainda por um belo e laborioso talento, que pretende que só a força pode domar o índio, e fazê-lo entrar na sociedade, que só por ela e pela servidão ou sujeição forçada poderá conseguir-se a sua redução" (Malheiro, 1976, v. 2, p. 248).

O belo e laborioso talento aludido pelo jurista mineiro pertencia a Francisco Adolpho de Varnhagen (1816-1878). Apesar de Perdigão Malheiro se apoiar nos dados concernentes aos índios de A História Geral do Brasil (1855) de Varnhagen, existe a contestação da idéia que preconizava a submissão dos índios à civilização branca e europeizada por intermédio da força, da guerra e da escravidão. Segundo Perdigão Malheiro, a guerra sistemática aos "índios bárbaros e cruéis" deveria ceder lugar a uma legislação que os considerasse como membros da nação.

Se não quiserem pelos meios brandos e suasórios abraçar a vida civilizada, não devem ser constrangidos pela força, pelo cativeiro ou servidão, e menos ainda perseguidos e destruídos; o homem civilizado, por isso que o é, não se deve mostrar bárbaro como o selvagem, ou mais bárbaro do que ele: se atacado, defenda-se, por que é este o Direito Natural, mas limite-se na defesa ao que for estritamente indispensável e justo, qualquer excesso não tem razão de ser, degenera em crime e em vingança ou ferocidade (p. 248-249).

Com efeito, tanto em José Bonifácio como em Perdigão Malheiro, caberia ao Estado imperial tomar as medidas necessárias para a civilização dos índios. Diferentemente de Varnhagen, para quem a "guerra tem sido um grande meio civilizador entre os homens", o Estado imperial deveria tanto prescindir da violência direta e da escravidão como difundir a educação entre as populações indígenas por intermédio da religião, da instrução primária, das artes mecânicas, das belas artes e do serviço militar. Perdigão Malheiro propunha o fortalecimento da iniciativa individual entre os indígenas, fato que os levaria a se metamorfosearem em membros da nação.

Cabe ressaltar que a imagem do índio bravo foi aceita tanto pelos adeptos da aplicação da violência direta quanto por aqueles que preconizavam a utilização da estratégia branda e conciliatória, com ambos reconhecendo tacitamente que a barbárie autóctone fora incitada pelas relações estabelecidas com os proprietários territoriais. Entretanto, Perdigão Malheiro previu que a integração dos índios à nação - ou o extermínio completo 
dos autóctones adversos à incorporação nos seus hábitos e costumes do cristianismo e da civilizaÇão européia ocidental - se daria de maneira proporcional à ocupação do território.

À proporção que o Estado crescer em população, em facilidade de comunicações por terra e por água, à proporção que o território se for cobrindo de mais povoados, e se forem descortinados os sertões onde principalmente eles hoje se abrigam, o facho da civilização abrirá caminho, espancando as trevas da selvageria, e ou eles se hão de necessariamente acolher nos braços do homem civilizado e confundir-se assim na massa geral da população, ou serão forçados a ceder o campo nessa luta desigual, em que a vitória conquanto incerta na época, é certa e infalível. (Malheiro, 1976, v. 2, p. 249, grifos meus).

Ocupação e povoação do território, restaurando uma autoridade pública que se mostrava indiferente ou perseguidora - nas citadas palavras do jurista mineiro, no caso dos Diretores das Aldeias. Transparece, assim, em Perdigão Malheiro, a vocação territorialista das elites políticas voltada para o controle da população, fossem elas adeptas da brandura e conciliação ou da violência direta.

Essa vocação denunciava a persistência da nossa herança ibérica, a qual fomentava o desenvolvimento das ambigüidades que perpassavam tanto a legislação colonial quanto a imperial referente aos indígenas. Fundado no exclusivo agrário e no trabalho compulsório, indígena ou negro, o Estado nacional brasileiro restaurou a estrutura econômica colonial. A herança do territorialismo ibérico estabeleceu uma relação ambígua com os preceitos liberais, uma vez que persistia, nas elites políticas que compunham o referido Estado nacional, o duplo objetivo de expansão territorial e domínio da população espalhada pelo território.

Nesse panorama, a questão de terras foi um instrumento importante para garantir o expansionismo territorial do Estado imperial. Em linhas gerais, essa expansão visava a atrair, mediante o pagamento de salário, a mão-de-obra indígena que estava à margem das propriedades fundiárias mais antigas. Por outro lado, na expansão das fronteiras do Império, tratava-se, em última análise, de se apropriar das terras indígenas.
Tanto a desapropriação de terras quanto a tentativa de se atrairem os indígenas como mão-de-obra livre para o trabalho nos latifúndios implicavam desapropriação de um território que sempre fora reconhecido como propriedade legítima e natural dos nativos.

Finalmente, na própria Lei de Terras de 1850 (...), fica claro que as terras dos índios não podem ser devolutas. O título dos índios sobre suas terras é um título originário, que decorre do simples fato de serem índios: esse título do indigenato, o mais fundamental de todos, não exige legitimação. As terras dos índios, contrariamente a todas as outras, não necessitam, portanto, ao ser promulgada a Lei de Terras, de nenhuma legitimação (Cunha, s.d., p. 141).

Apesar de José Bonifácio admitir essa desapropriação contínua das melhores terras dos indígenas, o autor veiculou estereótipos sobre os indígenas que não iriam de encontro tanto aos preceitos cristãos quanto ao trabalho disciplinado exigidos nas propriedades fundiárias. Esses estereótipos compunham os argumentos da maioria dos autores desde a colônia até o Império, defendessem ou não os sistemas de aldeias, a catequese, o princípio da guerra justa, os descimentos, os resgates, a aplicação das estratégias de brandura e conciliação ou violência direta ou a integração dos índios à nação.

No caso específico de Perdigão Malheiro, esse expansionismo territorial incutiria tanto a iniciativa individual quanto a inscrição dos índios como membros da nação, ou faria com que a civilização avançasse "nos sertões impelida por essa implacável força motriz da História que Gumplowicz, maior do que Hobbes, lobrigou, num lance genial, no esmagamento inevitável das raças fracas pelas fortes.” (p. 8). Entretanto, diferentemente de Euclides da Cunha, Perdigão Malheiro entreviu essa inelutável "força motriz da história" no "decreto de Deus Onipotente”, o qual levaria as populações indígenas à cristianização e civilização ou ao extermínio.

(Recebido para publicação em janeiro de 2006) (Aceito em abril de 2007) 


\section{REFERÊNCIAS}

ALENCASTRO, L. F. de. O trato dos viventes: formação do Brasil no Atlântico Sul. São Paulo: Companhia das Letras, 2000.

ANDRADA E SILVA, J. B. Projetos para o Brasil. São Paulo: Companhia das Letras, 1998.

CARDOSO, F. H. Capitalismo e escravidão no Brasil Meridional: o negro na sociedade escravocrata do Rio Grande do Sul. São Paulo: DIFEL, 1962.

CUNHA, E. Os sertões. 20.ed. rev. Rio de Janeiro: Ediouro, s.d

CUNHA, M. C. Política indigenista no século XIX. In: (Org.) História dos índios no Brasil. São Paulo:

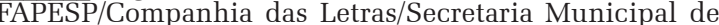
Cultura, 1992

IANNI, O. Raças e classes sociais no Brasil. 3.ed. São Paulo: Brasiliense, 1987
MALHEIRO, A. M. P. A escravidão no Brasil: ensaio histórico, jurídico e social. Petrópolis: Vozes, 1976. 3 v.

MELLO, J. M. C. O capitalismo tardio: contribuição à revisão crítica da formac̃ão e do desenvolvimento da economia brasileira. 7.ed. São Paulo: Brasiliense, 1988.

MONTAIGNE, M. Dos canibais. In:

5.ed. São Paulo: Nova Cultural, 1991. Ensaios.

MONTEIRO, J. O escravo índio, esse desconhecido. In: GRUPIONI, L. D. B. (Org.) Indios do Brasil. São Paulo: Secretaria Municipal da Cultura, 1992.

NOVAIS, F. A. Portugal e Brasil na crise do antigo sistema colonial (1777-1808). 6. ed. São Paulo: Hucitec, 1995

MOTA, C.G.; NOVAIS, F. A. A independência política do Brasil. 2. ed. São Paulo: Hucitec, 1996.

OCTAVIO, R. Os selvagens americanos perante o direito. São Paulo: Companhia Editora Nacional, 1946.

SKIDMORE, T. O negro no Brasil e nos Estados Unidos. Argumento: revista mensal de cultura. Rio de Janeiro, n. 1 , 1973.

\section{ALEGISLAÇÃOINDIGENA: Nação no Brasil}

\section{Carlos Henrique Gileno}

O principal objetivo do presente artigo é discutir alguns aspec- is to discuss some aspects of the tos das ambigüidades da legislação ambiguities of the indigenous indígena desde a colônia até a se- legislation from the colony period to gunda metade do século XIX no Bra- the second half of the century XIX in sil. Em última instância, aquelas Brazil. Ultimately, those ambiguities ambigüidades revelavam as tensões revealed the established tensions estabelecidas entre os poderes locais between the local powers and the e a metrópole lusitana, uma vez que Portuguese metropolis since the laws as leis expedidas pela coroa portu- sent by the Portuguese crown in faguesa em favor da liberdade dos ín- vor of the freedom of the Indians dios não foram efetivadas na práti- were not executed in practice, $\mathrm{ca}$, persistindo o cativeiro indígena persisting the indigenous captivity até a sua abolição formal em 1831. until his formal abolition in 1831. Entretanto, mesmo após a abolição, However, even after the abolition, the a defesa legal dos direitos indígenas legal defense of the indigenous rights seria um tema constante de intelec- would be a constant theme of tuais e políticos no decorrer da se- intellectuals and politicians during gunda metade do século XIX, já que the second half of the century XIX, a ausência daquela defesa impossi- since the absence of that defense bilitava a integração dos índios ao disabled the integration of the Estado-nação.

THE INDIGENOUS LEGISLATION:

\section{Carlos Henrique Gileno}

PALAVRAS-CHAVE: Legislação indígena no KEY-wORDS: Indigenous legislation in Brasil, escravidão indígena, Brasil Co- Brazil, indigenous slavery, Brazil lônia (1500-1822), Brasil Império Colony (1500-1822), Brazil Empire (1822-1889), Pensamento Político e (1822-1889), political and social Social no Brasil.

\section{LA LEGISLATION INDIGENE: ambiguïtés pour la formation de l'Etat- Nation au Brésil}

\section{Carlos Henrique Gileno}

L'objectif principal de cet article est de discuter de certains aspects con-cernant les ambiguïtés de la législation indigène pour la période allant de la colonie à la moitié du XIXe siècle au Brésil. Ces ambiguités révèlent enfin les tensions existantes entre les pouvoirs locaux et la métropole lusitaine. Vu que les lois promulguées par la couronne portugaise en faveur de la liberté des Indiens n'ont pas été effectivement mises en pratique, la captivité indigène a subsisté jusqu'à son abolition formelle en 1831 . Cependant, tout au long de la seconde moitié du XIXe siècle, même après l'abolition de l'esclavage, la défense légale des droits indigènes est toujours restée un thème d'intellectuels et d'hommes politiques puisqu'elle ne permettait pas l'intégration des Indiens à l'Etat-nation.

Mots-CLÉs: Législation indigène au Brésil, Esclavage indigène, Brésil Colonie (1500-1822), Brésil Empire (1822-1889), Pensée politique et sociale au Brésil.

Carlos Henrique Gileno - Doutor em Ciências Sociais pela Universidade Estadual de Campinas (UNICAMP), professor substituto do Departamento de Antropologia, Política e Filosofia da Universidade Estadual Paulista (UNESP, FCL, Araraquara), integrando o Laboratório de Política e Governo. È Diretor do Instituto Matonense Municipal de Ensino Superior (IMMES, Matão, São Paulo) e autor de artigos em revistas científicas brasileiras, sendo os mais recentes: Numa e a Ninfa: dilemas e impasses da formação da sociedade republicana. Perspectivas. São Paulo, v. 26, 2003; Escravidão Indígena no Pensamento do Cônego. Achegas.net: Rio de Janeiro, v. 19, 2004. Tem experiência em Sociologia, com ênfase em Pensamento Social brasileiro, Império, 1822-1889. Cultura e Política. Teoria Sociológica. 